Volume 5, Issue 2

September 2012

\title{
Stripping the Body in Contemporary Popular Media: the value of (un)dressing in American Telefantasy
}

\author{
MANJREE KHAJANCHI, Independent Researcher
}

\begin{abstract}
Research perspectives on identity and the relationship between dress and body have been frequently studied in recent years (Eicher and Roach-Higgins, 1992; Roach-Higgins and Eicher, 1992; Entwistle, 2003; Svendsen, 2006). This paper will make use of specific and detailed examples from the television programmes Once Upon a Time (2011-), Falling Skies (2011- ), Fringe (2008- ) and Game of Thrones (2011-) to discover the importance of dressing and accessorizing characters to create humanistic identities in Science Fiction and Fantastical universes. These shows are prime case studies of how the literal dressing and undressing of the body, as well as the aesthetic creation of television worlds (using dress as metaphor), influence perceptions of personhood within popular media programming. These four shows will be used to examine three themes in this paper: (1) dress and identity, (2) body and world transformations, and (3) (non-)humanness. The methodological framework of this article draws upon existing academic literature on dress and society, combined with textual analysis of the aforementioned Telefantasy shows, focussing primarily on the three themes previously mentioned. This article reveals the role transformations of the body and/or the world play in American Telefantasy, and also investigates how human and near-human characters and settings are fashioned. This will invariably raise questions about what it means to be human, what constitutes belonging to society, and the connection that dress has to both of these concepts.
\end{abstract}

\section{KEYWORDS}

Aesthetics, Body, Dress, Falling Skies, Fringe, Game of Thrones, Identity, Once Upon a Time, Telefantasy.

\section{Introduction}

For many decades, Science Fiction and Fantasy have enjoyed a continual presence on American television. From Twilight Zone (1959-1964) and The Addams Family (1964-1966) to more recent programmes such as Terra Nova (2011) and Once Upon a Time (2011- ), the process by which different television series create a range of believable worlds, from the 
Volume 5, Issue 2

September 2012

"realistic" to the (mostly) imagined, hold a vital role in understanding both the fascination with, as well as the resistance to, Science Fiction and Fantasy television. This article will scrutinize how recent American Telefantasy series (2008 onwards) appeal directly to the sentiments of the human existence and humanistic identities which feature in fantastical universes through the analysis of dress. I will explore how these programmes draw heavily upon theories of dress and identity. Examples derived from four specific Telefantasy series Once Upon a Time (2011- ), Falling Skies (2011- ), Fringe (2008- ), and Game of Thrones (2011- ) - demonstrate how dress acts as a metaphor integral to the perception of personhoodmaking and world building within contemporary popular media.

This article's methodology involved a three step process. Firstly, I conducted library research on textual sources of dress literature, after which I examined a broad selection of American Telefantasy series, paying particular attention to those examples which illustrated theories regarding dress studies. Finally, this focussed examination led to the selection of three themes I have identified as being central to an exploration of dress and identity in Telefantasy. The findings of this article are significant because, I believe, they help highlight the value that analysing the metaphorical uses of dress in Telefantasy can give us insight into how characters are constructed and, literally, fashioned, and how these Fantastical worlds are built. Other contemporaneous Telefantasy programmes that could also have been analysed (but which the word constraints of a study of this length preclude me from incorporating) include: Pushing Daisies (2007-2009), Sanctuary (2008-2011), Dollhouse (2009-2010), Warehouse 13 (2009- ), Torchwood: Miracle Day (2011), Terra Nova (2011), Alcatraz (2012), and Grimm (2011- ). Nevertheless, the three themes focused on in this paper are appropriate for all of the Telefantasy programmes mentioned, as well as many others.

I begin by defining the difference between "literal" dress and "dress as metaphor." I then introduce the three themes central to my analysis: (1) dress and identity, (2) body and world transformations, and (3) (non-)humanness. The crux of the argument will be provided by individual, description-heavy sections solely dedicated to each of the four Telefantasy series analysed. This involves delving into a thorough discussion regarding literal dress, body and identity within each show, where the importance of colour symbolism, attire, hairstyle and mannerisms provide an avenue for understanding character development. Meanwhile an examination of dress as metaphor, and the aesthetics of the universe(s) created in each show, will suggest how dress enables these Telefantasy worlds to "come alive." Following this, these findings will be amassed into an overarching synthesis, providing an insight into the mechanics of personhood- and world-building at work within the realm(s) of Telefantasy.

\section{Dress}

The thematic focus of this paper considers two forms of dress, literal dress and dress as metaphor. I use and understand the term dress to be very broad and all-encompassing in meaning. According to Joanne Entwistle (2001), 
Volume 5, Issue 2

September 2012

conventions of dress transform dress into something recognizable and meaningful to a culture and are also the means by which bodies are made 'decent', appropriate and acceptable within specific contexts. (Entwistle, 2001: 33)

Therefore, literal dress is understood to be more than a specific item of clothing worn by women. It shapes one's physical and social body (Douglas, 1973: 93), which invariably relates to personhood and identity. Literal dress refers to 'all forms of attire' (Welters and Lillethun, 2007: xix), including body modifications and body supplements (Roach-Higgins and Eicher, 1992: 1-8) which are either directly or indirectly added to the body (Eicher and Roach-Higgins, 1992: 15). Thus, literal dress has a direct relationship to the body, as it can not only lie outside the body, but also within or on the margins of the body (Barnes and Eicher, 1992: 1; Entwistle and Wilson, 2001: 1-2; Entwistle, 2003). Examples include tattoos, piercings, and corseted bodies, as well as a person's accent, posture, and gait. Keeping this extended definition in mind, literal dress incorporates costume, apparel, and one's whole ensemble. However, it would be a mistake to use these terms interchangeably, as none are as comprehensive in meaning as literal dress.

Conversely, dress as metaphor refers to how dress contributes to the representation of a "world" in a television series. One way of viewing a world presented within Telefantasy programmes is to understand it as a landscape dressed in colours - shades that set it apart from all other worlds. I understand this to be a metaphorical form of dress, where the aesthetics of the place is imbued with the symbolism of dress (i.e. a dressing of the universe).

One important aspect of Telefantasy that is customary across individual shows is that it injects the strange and abnormal into the realities of alternate universes (Johnson-Smith, 2005: 23). The unnatural, abstract, and impossible all become viable and understandable, as human rules and values change in this distant world of the unknown, through this framework. This creates a means for differentiation in worldly aesthetics, with the aim of convincing viewers of the plausibility of the existence of alien worlds (Johnson-Smith, 2005: 19), producing a 'look' that sets one television series apart from another (Geraghty, 2009: vii, xvi).

The differentiation between literal dress and dress as metaphor is the difference between dressing the (character's) body versus dressing the (virtual) universe. One relates to the identity of the person while the other relates to the identity of the show.

\section{Themes}

This paper elaborates on three themes, which are linked to literal dress and dress as metaphor, that are commonly found among all Telefantasy shows. I classify these themes as (1) dress and identity, (2) body and world transformations, and (3) (non-)humanness. A brief explanation of each is given here. 
Volume 5, Issue 2

September 2012

The first theme of dress and identity looks at the literal dressing of characters in Telefantasy series. This includes what colours the characters are associated with, as well as how they are dressed and accessorized for their show, with this aspect of styling being prioritised over the making of fashion statements. Whilst exploring the theme of dress and identity, these imagined characters are perceived as being "real" people (in relation to the environs of their Telefantasy "universe,") and are examined accordingly. Dress plays an important role in how people are understood or perceived by others and themselves, and a person's appearance is always interpreted in tandem with their personality and behavior. Therefore, a power suit may exude confidence and dominance and signals to others that the wearer means "business" (Entwistle, 2001: 53), whereas a doctor's uniform or police uniform identifies the person with a specific job and its associated duties (Craik, 2005; Giuntini, 2008). However, the carrying out of variety of responsibilities, and the appropriation of numerous roles, necessitates an emphasising of certain qualities/personas over others in different situations throughout the day. What is considered "proper" is dependent on situation and context (Entwistle, 2001: 38). Therefore, a person's identity can never be understood fully through analysing their literal dress on a singular occasion (Munns and Richards, 1999: 10; Svendsen, 2006: 79). Nevertheless, the relationship between literal dress and identity should not be undervalued, and all four of my chosen texts are analysed for patterns of dress, alongside mannerisms and expressions, to divulge identities of their characters that spanned whole seasons.

The second theme, body and world transformations, concerns the figurative dressing of people and their environments. It relates to the physical changes made to/experienced by a character's body, and the creation of universes different to our own. The aesthetics and "look" of the world and its people are not constrained by the traditional conventions of popular media. The impossible, the abstract and the strange are all depicted as "true" and possible through Telefantasy. The focus of this theme is on dress as a metaphorical technique; the degree to which worlds are transformed is visible through the creative setting of the universe. For example, the show Pushing Daisies takes place in the fictitious town of Couer d'Couers, which is showcased in vibrant and vivid colours and portrayed as extremely lively and cheery place. It exists as a backdrop for a story about a man who brings the dead back to life. Dressing Couer d'Couers as a dreamlike and idyllic environment allows the potentially sombre/macabre topic of death to be dealt with in a tender and romantic manner. The focus on dress as metaphor is also prevalent when bodies are modified, either from within or from the outside. Not only does the demeanor and guise of a transformed body change the character's outlook on life, but also our understanding of who that character is. In Dollhouse, the protagonist is a young woman who volunteers to give up her mind, body and identity to an organisation that has her mind wiped and replaced by various personalities, which are then hired out to clients for their personal use. Each time a new personality is imprinted, the character changes, and this is reflected in the way she talks, walks, and interacts with others. 
Volume 5, Issue 2

September 2012

The third theme, (non-)humanness, relates to the differing portrayals of humans, humanmachine hybrids, and human-alien hybrids. This theme explores the concept of "humanity," and what it means to be "human" (or "non-human"). Science Fiction and Fantasy storylines often deal with characters that are not-quite-human, whether due to magical, supernatural, or technological interventions. This theme is closely related to the second theme of body transformation and world transformation, as characters that undergo bodily transformations often need to demonstrate their humanness once again. Similarly, in cases where world transformations have occurred, where changes are made to the foundation and rules on which the universe is built, the nature and limits of humanness also change. Thus, the question arises of whether these altered humans, living in a transformed world, can be considered human or not. For example, the premise of Torchwood: Miracle Day, where the world's human population goes from being mortal to being immortal overnight, supposes that an eventual death is no longer a requirement for being considered human. In this situation, the theme of (non-)humanness is crucial to understanding how this transformation has changed the world's perception of life, and what it means to be human.

The upcoming sections on individual television shows will go into greater depth about each of these themes mentioned using context-specific examples. Due to the space constraints of this paper, only contemporary programmes are examined.

\section{Once Upon a Time}

The premise of the Fantasy series Once Upon a Time is that supposed "fairy-tale" characters are actually real people, and they live in the magic-filled Enchanted Forest. In order to deny all the other characters their happy endings, the Evil Queen (Lana Parrilla) casts a powerful dark curse that transports them into the town of Storybrooke, Maine, where the only happy ending will be hers. Storybrooke is a place without magic that exists in our world. It is foretold that only Snow White (Ginnifer Goodwin) and Prince Charming's (Josh Dallas) daughter Emma (Jennifer Morrison) is capable of breaking the Queen's curse. So an escape plan is executed that will protect baby Emma from the effects of the curse, but which makes everyone else forget who they are. The programme's main narrative occurs 28 years after the curse is enacted, when a twist of fate brings Emma to Storybrooke and back into their lives.

Once Upon a Time is thus set in two worlds, and the show's narrative interweaves scenes from both the enchanted world and the real world. The characters' dress codes are a significant factor in the process of differentiating between these two worlds. Storybrooke is situated in the real world, where characters dress in a manner to which viewers are able to relate - in suits, jeans, summer dresses etc. Meanwhile, the fairy-tale world showcases lavish costumes, gowns, and the kind of makeup and hairstyles that are usually reserved for special occasions, or feature in realms of make believe (i.e. theatre and film). 
Volume 5, Issue 2

September 2012

However, it is not only magic, but also time that is missing from the Storybrooke world. The curse orchestrated by the Evil Queen suspends the characters in a time loop where they neither age nor have distinct memories of their past, and their memories only return upon Emma's arrival. Thus, the "humanness" of the town residents, as well as that of their former fairy-tale identities, can be studied and questioned. Ironically, the characters in the Enchanted Forest, despite their magical natures, can be said to have more recognisably human qualities (virtues and flaws) than the ageless inhabitants of Storybrooke, who are unaware of their former identities (and, therefore, of who they really are), yet possess more recognisably "normal" outward appearances which substantiates their humanness. This is because all of the fairytale characters have shortcomings and make mistakes while living in the Enchanted Forest, regardless of their fated "happy endings." They often second-guess themselves and show their imperfection through their indecisiveness, whilst the inhabitants of Storybrooke live simplified and seemingly idyllic lives. However, the fairy-tale characters are content and satisfied with their way of life, while their "real world" counterparts are not. Therefore, this series continuously makes us question and critique the merits of being "human."

The relationship between both sets of characters is made evident through the way they are (literally) dressed. One such character that is easily recognizable between both worlds is Red (Meghan Ory), from the Little Red Riding Hood fairytale. In terms of the importance of colour symbolism, Red, or Ruby as she is called in the real world, is predominantly seen to wear red clothing in both worlds. Working as a waitress in her grandmother's café in Storybrooke, Ruby is usually dressed in red lipstick, red hair band, red nail polish, red highlights in her hair, red heels, red shorts, and even red buttons on her shirt. In the enchanted world, Red is usually seen draped in a full-length red riding cloak, with red gloves, and a red skirt. Not only is her dress indicative of who she is - both names obviously have direct associations to the colour red - it associates her with her "true" identity, as Little Red Riding Hood. She is the only character in Once Upon a Time that shows such an identical sense of dress in both worlds, making her fairytale identity easily noticeable wherever she is. Possibly, this may be because, in the well-known fairy-tale, her identity is intimately associated with the garments she wears and she is never referred to by name, while other fairy-tales put greater emphasis on characters' personalities and deeds. The writers of Once Upon a Time have given the character of Red a twist, however, revealed in 'Red-Handed' (01.15) that Red is cursed and is actually the ferocious and dreaded wolf herself. The reason she needs to wear her riding hood at all times is because it has magical powers that stop the transformation. Therefore, Red regularly undergoes a body transformation that changes her from human to animal and back again, further emphasising the uncertainty of whether she is more or less human as Red than as Ruby.

Another character, Mary Margaret, was named Snow White in the enchanted world and her original name has a big influence on how her character is dressed. Snow is always seen dressed in white gowns and white paraphernalia in the Enchanted Forest, her character being associated the attributes of virtue and innocence, as well as the colour white. This direct 
Volume 5, Issue 2

September 2012

relationship between name, dress and identity is very important when Snow has to go into hiding to save herself from the deadly wrath of the Evil Queen. In order to hide her identity and true self from others, she stops wearing anything white and is seen in neutral earth-toned shades instead. While her nature remains unchanged, the change in dress plays a vital role in signalling when Snow White is disguised. In contrast, her Storybrooke equivalent is neither identifiable through name nor the colour symbolism of her dress, as she is seen in an array of colours. Rather, it is her gentle disposition, simplicity and purity of heart that links her to her original identity. Therefore, as with Red/Ruby, the essential nature of her original identity remains.

Rumplestiltskin (Robert Carlyle), also known as The Dark One in the Enchanted Forest, and as Mr. Gold in the real world, has a very distinctive taste in dress. In the pilot episode (1.01), Rumplestiltskin's appearance is especially distinguishing, with glistening teeth, hardened fingernails, and glassy eyes. The sing-songy intonations in his voice also set him apart from everyone else and forms part of the repertoire of his literal dress. He is predominantly seen in metallic, shimmering colours within the enchanted world. The only exception occurs in the immediate aftermath of his bodily transformation into a powerfully magical being. In 'The Return' (1.19), he wears faded red and gray clothing, humble attire suggestive of his attempts to stay a "normal man" whilst his son lives with him. However, upon losing his son to another world (Ibid.), Rumplestiltskin allows himself to lead an extravagant lifestyle which is mirrored in the way he dresses. It is revealed in 'Skin Deep' (1.12) that the golden glint on his face is only due to the powerful magic he is infused with, and upon receiving love's true kiss from Belle (Emilie de Ravin), this glow slowly disappears to reveal the man behind the magic. This revelation emphasises how Rumplestiltskin undergoes an immense body transformation when he is imbued with magical powers, and becomes 'The Dark One' (as seen through the change in his literal dress).

Unlike Rumplestiltskin, who has a messy appearance and shoulder length shaggy hair, Mr. Gold is often shown wearing a suit and tie, using a cane, and keeps his smooth hair tamed. Mr. Gold is a businessman who owns the town of Storybrooke and this status is reflected in his dominating dress sense. He is feared by everyone in Storybrooke, as Rumplestiltskin is in the fairytale world, but his power comes from his wealth rather than his magic. Like Snow White, Mr. Gold's name also has a special meaning, associated, as he is, with wealth. Simultaneously, the character of Rumplestiltskin is also linked to gold and other shimmering hues through his makeup and attire. Therefore, these similarities in colour symbolism serve to further associate Mr. Gold with his original persona.

Once Upon a Time invites viewers to question who is human and who is not, and which universe most accurately mirrors our society. It engages with the paradoxical notion of what it would be like if happily-ever-after fairytale characters made humanlike mistakes while their real world counterparts are little more than pawns in someone else's game. Literal dress is an important prop, used to demarcate the barrier between both worlds, and plays a vital role in bringing the identities of the characters depicted in the universes into the limelight. 
Volume 5, Issue 2

September 2012

\section{Falling Skies}

Falling Skies is one of many television shows 'based upon a projection into a potentially frightening future' (Kaminsky and Mahan, 1985: 115), which holds both promise and danger. It is set in the year 2012, a few months after alien beings have invaded the world. The survivors' way of life drastically changes, as all electronics stop working, cities are destroyed, and most soldiers have been killed, causing laypeople to take up arms and join the fight against alien forces. According to 'Live and Learn' (1.01), there are millions of alien creatures inhabiting Earth, who kill adults and take children away from their families, affixing them with harnesses for reasons unknown. Three types of aliens are seen in the series: armor-wearing, soldier-like six-legged insectoids called skitters; robotic gun-wielding drones called mechs; and slender metallic humanoids that are, at the time of writing, unnamed.

With the arrival of skitters, the dynamics of life on Earth is rewritten in this post-apocalyptic universe. Thus, the world is transformed into a battlefield, and survivors band together to hide and strengthen their forces in order to increase their chances of survival. Groups, consisting of civilians and fighters, start to live a semi-nomadic lifestyle, carrying their belongings from place to place in anything they can find. Barricades are formed out of now useless cars and tyres, while warm clothes, medical supplies, and the few motorcycles and older model cars that can be salvaged are greatly valued. Likewise, with the lack of artificial lighting, the world of Falling Skies is thrown into a perpetual darkness, where camp fires and lanterns come into regular use. Thus, the technological world is transformed into a landscape littered with debris and rubble where survival is the key concern.

Throughout the series, fighters are shown wearing faded camouflage clothing and fingerless gloves, while civilians are shown in normal jeans and t-shirts - a quintessential 'transnational style' of clothing (Welters and Lillethun, 2007: xxi) - with suits and smart clothing completely discarded from people's wardrobes. Regardless of their roles, everyone in the show carries around memorabilia from their lives before the invasion, whether it is photographs, wedding rings, or other small trinkets. Despite this, individual identities are replaced by a collective group identity, much like in a military regime, where brotherhood and loyalty to the community take precedence over individual concerns. Falling Skies is different from many other programmes in that it portrays dress and identity, not to separate individuals, but to unify and homogenize the survivor community. Therefore, dress does not distinguish personalities apart, instead being used as a means to reflect their current situation and the surrounding environment. This is why everyone in the show is similarly dressed in shabby and worn out clothes and encrusted in dust, making it aesthetically hard to distinguish one face from another in the group, and literal dress is used as a means to accentuate the world transformation that has occurred since the invasion. 
Volume 5, Issue 2

September 2012

A similar collective mentality also exists among the skitters, and the captured children on whom the harnesses have been attached. 'Prisoner of War' (1.03), reveals that the harnesses transform the bodies of the hosts by injecting drugs directly into the children's spine, resulting in the spine growing roots which attach the harness to the back of the child, enabling them to be controlled by the skitters. These roots are a body modification associated with dress that forms part of the harnessed children's identities. Children are then used as a labour source to scrounge scrap metals for the aliens (Ibid.).

However, in 'Silent Kill' (1.05), skitters are shown to be caring and loving beings that are protective of the harnessed children under their command, much like a human family unit. A major revelation in 'What Hides Beneath' (1.08) supports this view, when it is revealed that skitters had also been harnessed originally, signifying that they could have once been human beings that transformed into these alien creatures. Thus, removing the harnesses does not automatically terminate the transformative process whereby harnessed humans gradually turn into alien skitters. For instance, in the case of Ben (Connor Jessup) and Rick (Daniyah Ysrayl), two children that have their harnesses removed - but not before the process had begun - are now in a liminal phase of being neither alien nor human. The needles protruding along their spines distance Ben and Rick from the rest of the human group, as they instil a fear of the non-human among the onlookers. Due to the body modifications that occurred due to the needles, and the knowledge that this may be the beginning of their transformation from human to skitter, there exists a high degree of uncertainty concerning the humanness of the harnessed children.

Rather than focusing upon the individual characters within the show, Falling Skies highlights the group mentality of survivors, making the metaphorical dressing of the universe thematically more important than the literal dressing of the individuals. As a close-knit group fighting for survival, they are very particular about who counts as one of them and who counts as the enemy, and there is an important distinction made between who is human, and who is alien. This labelling puts characters that have undergone transformations due to the harnessing process in an unenviable and distressing position, where their humanness is constantly being questioned.

\section{Fringe}

Fringe focuses on a special task force set up by Homeland Security, called Fringe Division, which investigates strange and unexplained phenomenon, known as fringe events. The team consists of FBI agent Olivia Dunham (Anna Torv), a formerly-institutionalized fringe scientist Dr. Walter Bishop (John Noble), his son Peter (Joshua Jackson), federal assistant Astrid Farnsworth (Jasika Nicole), and, in season four, special agent Lincoln Lee (Seth Gabel). In the course of four seasons, the Fringe "universe" has slowly expanded to include parallel universes and alternate timelines. There is the original universe which is comparable to our world today, and a parallel universe where parallel versions of Fringe team members 
Volume 5, Issue 2

September 2012

exist in a slightly different version of the world as we know it. Then, in season three's finale, Peter, vanishes from both universes, and this spurs the creation of an alternate timeline which bridges both universes together. In this alternate timeline, no one in the original or parallel universe has any memory of Peter (as he has been erased from time). Even upon his reemergence into the alternate timeline, the new timeline remains intact, and he remains unknown to the rest of the Fringe team.

While the original universe has no obvious differences to the world we live in, minus the supernatural occurrences that are common in the world of Fringe, the parallel universe is usually differentiated through a visual technique of showing an establishing shot of a bronze Statue of Liberty, rather than the traditional copper one, and a panoramic view of New York City with the World Trade Center still standing post 9/11. As some episodes take place in one universe and other episodes in the other universe, multi-coloured title sequences make it explicit in which universe the majority of the episode's narrative will occur - blue for the original universe, red for the alternate one, with episodes taking place in both equally having a combination of blue and red title sequences. After the introduction of the alternative timeline in season four, all episodes have an amber title sequence. Colour coding the universes through the sequences is an effective way to dress the show, as it punctuated the world transformations between universes and made the differences between universes clearer.

In terms of world transformation and world building, how the Fringe Division in each universe is portrayed and dressed is important to note. The Fringe Division in the original universe is a covert branch of the government that work out of an obscure basement laboratory in Harvard University, which looks old and dated, and where everyone is seen wearing a combination of pant suits and the iconic jeans and t-shirt (English, 2007: 91). In contrast, the non-secretive Fringe Division in the parallel universe is a high-tech, laudable component of the government, often dressed in sleeker, military clothing, not to mention the unique ear pieces worn for communication purposes by all members.

As the storyline becomes more complex, doppelgangers from the parallel universe are introduced as are the idiosyncrasies between universes. At times, the differences between universes, or the differences in personality between two versions of a character, are so minute that literal dress plays an important role in helping the audience differentiate between them. As the show progresses, subtle differences become noticeable between original cast members and their parallel counterparts. Hair colour is different for Olivias between universes, with one sporting blond hair, the other red. Similarly, the original Astrid wears earrings while the alternative has red highlights in her hair. Captain Lee (in the alternate universe) and Agent Lee (from the 'original,' though introduced into the narrative after his doppelganger) are distinguishable as Agent Lee is wears glasses while Captain Lee does not and sports funkier, spiky hair. Furthermore, the original Dr. Bishop is shown to be a scientist with shaggy hair, wearing a lab coat and normal clothes, while the parallel version, the Secretary of Defence, is dressed in a power suit, and wears his hair in a more coiffured style. Everyone has their own distinct identity, but depending on consistencies between their upbringings and personal 
Volume 5, Issue 2

September 2012

histories, the differences in dress and identity between character versions can be determined in the show.

One final aspect of Fringe that requires assessment is the role and presence of a group of beings known as the Observers, and their (non-)humanness. In 'The End of All Things' (4.14), Observers are revealed to be members of a scientific team from one of many possible futures that have code names and advanced physical abilities, including being able to walk through walls, read people's minds, and catch bullets (2.08, 'August'). They are not limited by our perception of time and show up at important moments in the earth's history to collect data and witness events deemed interesting. Observers are present in every episode of Fringe (often featuring in quick cameos) and are characterised by their striking physical appearance they are bald, do not have eyebrows, dress in black suits and hats, and carry with them a briefcase, a mobile communication device, and a notebook that they fill with an unknown language script. These are all aspects that make up their literal dress. Not only is their manner and dress distinctive, but their humanness is also debatable, especially since they do not feel emotions (Ibid.). However, when it is revealed that they have evolved from human beings and are, essentially, our descendants ('The End of All Things'), the viewer is forced to consider whether this means they are still inherently human.

\section{Game of Thrones}

Game of Thrones is a period Fantasy series based on the novels written by George R. R. Martin and set in a universe which recalls Medieval Europe, where rivalling kingdoms fight wars with armored soldiers on horseback. Locations represented so far in the Game of Thrones universe include The Seven Kingdoms of Westeros, the lands across the Narrow Sea, and the vast unknown beyond The Wall, which marks the edge of The Seven Kingdoms. The most distinctive feature of this world is the exceedingly long weather seasons, where winters and summers can last up to a decade at a time. This universe is very different to our own, and is highly dependent on world transformation through the creation and dressing of this complex landscape.

The lands across the Narrow Sea are occupied by many different peoples, including the Dothraki. The Dothraki are clans of horse riding warriors who raid and plunder neighboring lands and take slaves on a regular basis. The people of Westeros consider them to be subhuman savages, beasts, and ferocious killers. The same is believed of the Wildlings, free people who live beyond the Wall, who are thought to be uncultured and untamed with no allegiances and loyalties to the kingdoms. The programme advances a "colonial" belief that, if a people are not settled, have no ties to land, or show no allegiance to a ruler, they are not evolved humans. The portrayal of the different lifestyles, cultural norms and ethics of the diverse races and social groups living within the Game of Thrones landscape results in an implicit questioning of the humanness of the various characters. 
Volume 5, Issue 2

September 2012

"The Wall" is enormous, and composed of solid ice that runs along the northern boundary of The Seven Kingdoms. It is a defence against the Wildlings and other mysterious supernatural beings that live beyond it. It is guarded by the Sworn Brothers of the Night's Watch, a group of celibate men who devote their lives to battling any enemy which may seek to disrupt the relative harmony of The Seven Kingdoms. Black and white colour symbolism is apparent in the creation of Wall landscape, as men of the Night's Watch are dressed in black, associated with night, and ride black horses when they patrol the realm's snow-covered Wall. Therefore, the Wall can be viewed literally and figuratively as a "black and white" setting, where good fights evil, defending against the unknown. Across a white snowy and wintery backdrop, these men of the Night's Watch keep monsters called White Walkers at bay - blue-eyed beings thought to be extinct thousands of years ago that rise up from the dead. The colour white is associated with death, the cold, winter, and misery. Likewise, the blue eyes of the White Walkers signify the ice-cold nature of these not-quite-human creatures that pose a looming threat to the inhabitants of The Seven Kingdoms. These former-humans have undergone a body transformation that makes a frightening force with no shred of humanness left in them.

Along with colour, dress also plays an important part in creating believable characters and, in turn, a believable universe for the series. Arya (Maisie Williams) and Daenerys (Emilia Clarke) are two characters that show the greatest degree of body transformation through dress. Arya Stark is the youngest daughter of Ned Stark, the Hand of the King (Sean Bean), and has a gender-neutral, later gender-bending, role in the show. Dressed as a lady in the first few episodes, Arya is seen wearing boys' clothes for the first time during her first sword fighting lesson in 'Lord Snow' (1.03). Her “dance master," Syrio (Miltos Yerolemou), also refers to her as a boy during training, and later Arya is heard telling her father that she does not want to be a lady at all. It is around at this time that Arya seems to have a body transformation that shifts her female identity into something more gender-neutral. This transformation coincides with her increasing skill in handling her sword, a male symbol, which she calls Needle. More than once, Arya is mistaken for a boy due to her actions, behavior and looks (1.05, 'The Wolf and the Lion'), and upon the execution of her father, a man from the Night's Watch cuts her long hair and disguises her as a boy (1.10, 'Fire and Blood') in order to escort her safely home, completing her transition into a non-female. By this time, not only has her style and choice of dress changed, but her sword becomes a permanent fixture of her wardrobe, and her actions and behaviour is associated with that of a young boy more than that of a young girl. Thereafter, her name changes frequently, and her life takes many turns, alluding to the shifting identities she portrays throughout the second season. Her name, dress, and identity oscillates between male and female roles and she is able to adjust transform herself for these new roles with ease. Needle remains with her throughout her journey to self discovery, becoming an integral part of her literal dress and her identity.

Daenerys Targaryen also undergoes a body transformation as she gains status and power. Daenerys is the last surviving heir to the Iron Throne of Westeros, and has been living in 
Volume 5, Issue 2

September 2012

exile for many years. Following the death of her brother Viserys (Harry Lloyd), she is determined to destroy those who stole her inheritance from her and reclaim her rightful place as the ruler of The Seven Kingdoms. This conviction to regain what she is owed is also mirrored in her sense of dress (and undress), which accurately denotes her changing social status. At the beginning of the first season, Daenerys is at the mercy of her brother Viserys as she is married off to the Dothraki Khal Drogo (Jason Momoa) for leverage (1.01, 'Winter is Coming'). On their wedding night, the young and naïve Daenerys is embarrassed and ashamed of being naked in front of Drogo. This is recalls Entwistle's (Entwistle, 2001: 48; Entwistle, 2003: 97) observation that act of stripping in front of others often prompts a sense of shame, for revealing one's nakedness links people to the animalistic, where walking around unclad at all times is normal (Soper, 2001: 17). However, nakedness can be seen as a marker of Daenerys' identity (Svendsen, 2006: 77; Vincent 2009: 162) as she is often seen naked performing her marital duties. Adapting to the Dothraki way of life proves difficult for Daenerys, who is forced to sit atop a horse all day, learn to eat an unfamiliar and unappetising diet, and the frequent handling gives her callous-ridden hands. Daenerys only starts dressing in the Dothraki manner after she starts fulfilling her role as their queen (which involves pleasuring Drogo sexually, and learning to command her people (1.03)). It is also at this time that she learns she is pregnant, which transforms her body and identity further.

Meanwhile, the association between Daenerys' naked body and a sense of shame is gradually eroded by instances where her nakedness occurs in close proximity to fire. There are various moments throughout the Game of Thrones when Daenerys is seen submerged in or touching fire or scalding, hot embers. A notable example involves her walking into Drogo's funeral pyre carrying three dragon eggs, re-emerging naked, alive and unscathed, along with three hatched baby dragons ('Fire and Blood'). Similarly, in 'Valar Morghulis' (2.10), to save her dragons and herself from capture, Daenerys instructs them to breathe fire, destroying everything and everyone in their way, including her own clothes, while she remains unharmed. Thus Daenerys symbolically transforms into a kind of dragon herself. Transforming into a dragon, or at least the "mother" of dragons changes her from being powerless and naïve into a powerful entity in her own right (see Soper, 2001: 17). The dragons also make up part of her ephemeral body and associated dress, especially since they do not have distinct identities or make autonomous decisions of their own. Because literal dress relates to personality and body modifications as much as clothes, Daenerys' transition from girl to wife to queen to mother to dragon is apparent even through her undress. Her change from being shamed to being unashamed at being naked comes from her shift from human to non-human. As a character who feels no pain from fire, and her self-identification as a dragon, Daenerys' humanness is radically altered throughout the two seasons. She no longer believes herself to be a mere human, giving her a supra-human identity

Game of Thrones is about a universe that has many similarities to recognisable historical periods in our own world; a time of warfare in a world of bloodshed. It is also a world where powerful supernatural forces are at play and the subject of non-humanity can be broached. 
Volume 5, Issue 2

September 2012

Understanding the role that dress plays in this universe, as the marker of identity among characters, helps us to understand why others may view certain people, like the Dothraki and the Wildlings, as sub-human, and others, like Daenerys, as supra-human.

\section{Synthesis}

Characters inhabit different contexts in each show, therefore, labelling all of these disparate shows as forms of American Telefantasy allow them to be grouped together under a common category, in such a way that this paper's three themes of dress and identity, body and world transformation, and (non-)humanness can be linked and compared on a level plane across all four programmes (see Johnson, 2005: 146-147).

The time periods in which these programmes occur are distinctive and often non-linear. Falling Skies, Fringe, and the Storybrooke world in Once Upon a Time are set in what viewers would recognise as 'present day,' whereas the Enchanted Forest in Once Upon a Time appears to exist in a timeless period. Game of Thrones, meanwhile, is ostensibly set in the past - but not a past that necessarily coincides with our timeline's history. An example of this is that the horse-riding Dothraki in Game of Thrones do not resemble any historical peoples that we know of. These details and discrepancies assist in making the worlds of Telefantasy different from our own. Often the use of colour symbolism in portraying different people and places also aids in the creation of fantastical settings that look vastly different from the "real" world, as well as from other fantastical settings within the same fictional world - whether it is the starkly black and white colours associated with the Wall in Game of Thrones, or the use of colour differentiation in distinguishing between parallel universes in Fringe.

A common thread of Telefantasy is that it takes human issues and concern for the future and presents them onscreen through imaginative means. Even dystopic and perilous worlds, regardless of whether they relate to our own world's past or future, may all be perceived as forward-thinking as they encourage us to suspend our disbelief and ask what if... In this manner, our own ideas regarding the superiority/inferiority of differing social groups and the consequences of fighting for power is tackled by Game of Thrones, while our fear for the unknown and the 'other' is discoursed in Fringe and Falling Skies. Therefore, the advancement of society is often shown as a hazardous process:

Some critics have related [Telefantasy] to fear of the future and to concern about the meaning and possible dangers of progress. Against this concern, there has been a kind of faith in the future in spite of the dangers involved. (Kaminsky and Mahan, 1985: 116)

Therefore, hopes are invariably linked to the future and success of humankind to some degree. Even in the face of human extinction, as in Falling Skies, where the world is dressed 
Volume 5, Issue 2

September 2012

and portrayed as bleak and unpromising, it is the determination and resolve of the characters that shines through. It is their mental strength that permeates their identity and who they are, made manifest in their literal dress. The landscape of Fringe is set up in such a way that it lets us compare how multiple universes were built side to side. We can see clearly how even small decisions made by humans can change what someone thinks or believes in the future. To some extent, all the shows mentioned in this paper, as well as many other Telefantasy programmes, comment upon the future of humanity, providing insight into one or more possible futures. Questions of how it will change society and people, how it can be reversed, or how people can adapt to this new future are all issues that can be broached through this topic. Exploring dress themes can help us to pinpoint how different characters react to these issues.

The role of humans and humanity in these future/alternative possibilities is both relevant and pressing. What constitutes a human and what qualities a human should have are both questions that every show analysed in this paper has questioned. Programmes such as Once Upon a Time spend the majority of their narrative discussing this concept. Can fairy-tale characters that are imaginary be "human?" Can humans who have forgotten their identity? Furthermore, we find that questions regarding humanness rely as much on addressing concerns over who is not human, and what makes certain traits markers of non-humanness. Further examples rife for investigation for their not-quite-humanness include the dubious identity of harnessed children in Falling Skies, and the reasoning for supra-being Daenerys's uncanny ability to survive consecutive trials by fire in Game of Thrones. Assessing how the world is built and how the programmes demarcate natural from unnatural phenomenon in these fictitious universes through dress, can help provide answers. One question that all Telefantasy needs to address is whether characters and television shows that portray forms of body or world transformations can ever represent full "humanness." Regardless, who is human and who is not is a complex and compound question, and can hardly be answered with a yes or no answer. Rather, it is the degree of humanness presented by each character that is more interesting to examine, as the corresponding layers of analysis evidently provide stimulating and provocative interpretations.

\section{Conclusion}

This paper has examined how four contemporary examples of American Telefantasy have benefited from utilising a thematic focus on dress to support the aesthetics of the universe(s) created for each series. As all Telefantasy shows follow different formats and present diverse truths through different ways of telling stories, the methods by which universes are built follow dissimilar paths. However, this paper has highlighted the impact and necessity of thinking about dress and undress - both literal and metaphorical - when creating any form of Telefantasy, as it plays an important role not only in understanding the fictional realities, but also in reflecting upon questions that relate to the human existence. 
Volume 5, Issue 2

September 2012

Telefantasies construct realities through the building of environments, within which characters and narratives are situated. Dressing the landscape of the show through world transformation, then, becomes an important aspect for selling the reality of the fictional world to viewers. The degree to which a world is transformed relates to how the characters living in that world are identified as human or non-human. Humanness is an important feature of all Telefantasy, as the quintessential question of who is human, and what being human entails, is a recurring theme in this genre. Hence, dressing and undressing aspects of a world and its characters become good indicators of world building and degree of humanness within Telefantasy series. Often, this subject is broached when dealing with supernatural, magical, or body transforming characters that have different or additional qualities to typical humans. Likewise, the question of humanity is customary when a character's behaviour, posttransformation, can no longer be related to human qualities. It is in these situations that the non-humanness of characters is suggested.

I would argue that, without taking into account the body or dress of characters, as viewers, we fail to comprehend the full meaning of a programme. Ideas inherent within Telefantasy series which are conveyed through world building remain fragmentary, even elusive. It is necessary to understand each character through their literal dress within the context of that show, before the value and importance of analysing his or her dress and identity can be discerned. As dress can have infinite meanings, contextualizing the use and need for dress within each show brings greater understanding of plot, character development, and the themes that offered in Telefantasy.

\section{References}

Barnes, R. and Eicher, J. B. (1992) 'Introduction' in Barnes, R. and Eicher, J. B. (Eds.) Dress and Gender: making and meaning in cultural contexts. New York: Berg, pp.1-7.

Craik, J. (2005) Uniforms Exposed: from conformity to transgression. Oxford: Berg. Douglas, M. (1973) Natural Symbols: explorations in cosmology. London: Barrie and Jenkins.

Eicher, J. B. and Roach-Higgins, M. E. (1992) 'Definition and Classification of Dress: implications for analysis of gender roles' in Barnes, R. and Eicher, J. B. (Eds.) Dress and Gender: making and meaning in cultural contexts. New York: Berg, pp.8-28.

English, B. (2007) A Cultural History of Fashion in the Twentieth Century: from the catwalk to the sidewalk. Oxford: Berg.

Entwistle, J. (2001) 'The Dressed Body' in Entwistle, J. and Wilson, E. (Eds.) Body Dressing. New York: Berg, pp.33-58.

Entwistle, J. (2003) 'The Dressed Body' in Evans, M. and Lee, E. (Eds.) Real Bodies: a sociological introduction. New York: Palgrave, pp.133-150. 
Volume 5, Issue 2

September 2012

Entwistle, J. and Wilson, E. (2001) 'Introduction: body dressing' in Entwistle, J. and Wilson, E. (Eds.) Body Dressing. New York: Berg, pp.1-9.

Geraghty, L. (2009) 'Introduction: future visions' in Geraghty, L. (Ed.) Channelling the Future: essays on science fiction and fantasy television. Lanham, MD: Scarecrow Press, pp.vii-xviii.

Giuntini, P. (2008) 'Uniformly So' in Giuntini, P. and Hagen, K. (Eds.) Garb: a fashion and culture reader. Upper Saddle River, NJ: Pearson Prentice Hall, pp.33-35.

Johnson, C. (2005) Telefantasy. London: British Film Institute.

Johnson-Smith, J. (2005) American Science Fiction TV: Star Trek, Stargate, and beyond. Middletown, CT: Wesleyan University Press.

Kaminsky, S. M. and Mahan, J. H. (1985) American Television Genres. Chicago: NelsonHall.

Munns, J. and Richards, P. (1999) 'Introduction: "the clothes that wear us"' in Munns, J. and Richards, P. (Eds.) The Clothes That Wear Us: essays on dressing and transgressing in eighteenth-century culture. Newark: University of Delaware Press, pp.9-36.

Roach-Higgins, M. E. and Eicher, J. B. (1992) 'Dress and Identity,' Clothing and Textile Research Journal, 10(4), pp.1-8.

Soper, K. (2001) 'Dress Needs: reflections on the clothed body, selfhood and consumption' in Entwistle, J. and Wilson, E. (Eds.) Body Dressing. New York: Berg, pp.13-32.

Svendsen, L. (2006) Fashion: a philosophy, trans. J. Irons. London: Reaktion.

Vincent, S. J. (2009) The Anatomy of Fashion: dressing the body from the Renaissance to today. Oxford: Berg.

Welters, L. and Lillethun, A. (2007) 'Introduction' in Welters, L. and Lillethun, A. (Eds.) The Fashion Reader. Oxford: Berg, pp.xix-xxii.

\section{Teleography}

The Addams Family. (1964-1966) U.S.A.: Filmways Television.

Alcatraz. (2012) U.S.A.: Warner Bros. Television/Bad Robot/Bonanza Productions/Alcatraz Films.

Dollhouse. (2009-2010) U.S.A.: $20^{\text {th }}$ Century Fox Television/Boston Diva Productions.

Falling Skies. (2011- ) U.S.A./Canada: Dreamworks Television/Invasion Productions.

- ' 'Live and Learn,' Falling Skies. Episode 1.01. Dir. Carl Franklin. Turner Network Television. 2011, June 19. 
Volume 5, Issue 2

September 2012

- 'Prisoner of War,' Falling Skies. Episode 1.03. Dir. Greg Beeman. Turner Network Television. 2011, June 26.

- 'Silent Kill,' Falling Skies. Episode 1.05. Dir. Fred Toye. Turner Network Television. 2011, July 10.

- 'What Hides Beneath,' Falling Skies. Episode 1.08. Dir. Anthony Hemingway. Turner Network Television. 2011, July 31.

Fringe. (2008- ) U.S.A./Canada.: Warner Bros. Television/Bad Robot/Fringe Element Films/FB2 Films.

- 'August,' Fringe. Episode 2.08. Dir. Dennis Smith. Fox Network. 2009, November 19.

- 'The End of All Things,' Fringe. Episode 4.14. Dir. Jeffrey G. Hunt. Fox Network. 2012, February 24.

Game of Thrones. (2011- ) U.S.A./U.K.: Home Box Office/Grok! Television/Generator Entertainment/Television 360/Bighead Littlehead.

- 'Winter is Coming,' Game of Thrones. Episode 1.01. Dir. Timothy Van Patten. Home Box Office. 2011, April 17.

- 'Lord Snow,' Game of Thrones. Episode 1.03. Dir. Brian Kirk. Home Box Office. 2011, May 1.

- 'The Wolf and the Lion,' Game of Thrones. Episode 1.05. Dir. Brian Kirk. Home Box Office. 2011, May 15.

- 'Fire and Blood,' Game of Thrones. Episode 1.10. Dir. Alan Taylor. Home Box Office. 2011, June 19.

- 'Valar Morghulis,' Game of Thrones. Episode 2.10. Dir. Alan Taylor. Home Box Office. 2012, June 3.

Grimm. (2011- ) U.S.A.: Universal TV/Hazy Mills Productions/GK Productions.

Once Upon a Time. (2011- ) U.S.A.: ABC Studios/Kitsis \Horowitz.

- 'Pilot,' Once Upon a Time. Episode 1.01. Dir. Mark Mylod. American Broadcasting Company. 2011, October 23.

- 'Skin Deep,' Once Upon a Time. Episode 1.12. Dir. Milan Cheylov. American Broadcasting Company. 2012, February 12.

- 'Red Handed,' Once Upon a Time. Episode 1.15. Dir. Ron Underwood. American Broadcasting Company. 2012, March 11.

Pushing Daisies. (2007-2009) U.S.A.: Warner Bros. Television/Jinks/Cohen Company/Living Dead Guy Productions.

Sanctuary. (2008-2011) Canada/U.S.A.: Stage 3 Media/Sanctuary 1 Productions.

Terra Nova. (2011) Australia/U.S.A.: 20th Century Fox Television/Amblin

Television/Kapital Entertainment/Chernin Entertainment/Siesta Productions. 


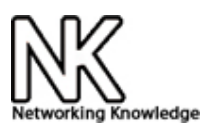

Volume 5, Issue 2

September 2012

Torchwood: Miracle Day. (2011) U.S.A./U.K.: BBC Wales/BBC Worldwide Productions/Starz Originals.

The Twilight Zone. (1959-1964) U.S.A.: Cayuga Productions/Columbia Broadcasting System.

Warehouse 13. (2009- ) U.S.A.: Universal Cable Productions/Syfy. 